\title{
Homocysteine and vitamin therapy in stroke prevention and treatment: a review
}

\author{
Bogdan N. Manolescu ${ }^{1 凶}$, Eliza Oprea², Ileana C. Farcasanu², Mihai Berteanu ${ }^{3,4}$ \\ and Cornelia Cercasov²
}

'Department of Biochemistry, School of Medicine, University of Medicine and Pharmacy "Carol Davila", Bucharest, Romania; 'Department of Organic Chemistry, Faculty of Chemistry, University of Bucharest, Bucharest, Romania; 'Department of Rehabilitation and Physical Medicine, School of Medicine, University of Medicine and Pharmacy "Carol Davila", Bucharest, Romania; "Department of Rehabilitation and Physical Medicine, University Emergency Hospital ELIAS, Bucharest, Romania

\begin{abstract}
Homocysteine (Hcy), a sulfur amino acid, is the only direct precursor for L-methionine synthesis through a reaction that requires vitamin $B_{12}$, representing a connection with "one-carbon" units metabolism. Hcy catabolism requires vitamin $B_{6}$ and as a consequence, alteration in folic acid and B vitamins status impairs Hcy biotransformation. Numerous studies have indicated that Hcy is an independent risk factor for cardio- and cerebrovascular diseases. In the last decade, several clinical trials have investigated the possible correlation between the use of folic acid and vitamins $B_{6}$ and $B_{12}$ for lowering Hcy plasma concentration and the reduced risk of stroke or its recurrence. This review is aimed to present some aspects of Hcy biochemistry, as well as the mechanisms through which it exerts the toxic effects on the vascular endothelium. We also discuss the results of some of the clinical trials developed to investigate the beneficial effects of vitamin therapy in the prevention and management of stroke.
\end{abstract}

Keywords: homocysteine, stroke, folic acid, vitamin $B_{6}$, vitamin $B_{12}$ vitamin therapy

Received: 14 June, 2010; revised: 02 November, 2010; accepted: 28 November, 2010; available on-line: 06 December, 2010

\section{INTRODUCTION}

Stroke is a major cause of morbidity and mortality worldwide. Many studies indicate a plethora of conventional risk factors for stroke (i.e., hypertension, dyslipidemia, smoking, diabetes mellitus, obesity, and family history). Nevertheless, cerebrovascular events can occur sometimes in individuals without any of the previously mentioned risk factors. As a consequence, it is very likely that other risk factors exist. Hyperhomocysteinemia, defined as an elevated plasma total homocysteine (tHcy) concentration $(>10 \mu \mathrm{M})$, is one such factor. There is epidemiological evidence suggesting a relationship between hyperhomocysteinemia and increased risk of a broad range of neurodegenerative conditions, including Alzheimer and Parkinson disease, and stroke (Mattson \& Shea, 2003; Zou \& Banerjee, 2005).

\section{METABOLIC PATHWAYS OF HOMOCYSTEINE}

In mammalian cells, Hcy metabolism involves one pathway for biosynthesis and three Hcy consuming path- ways (Fig. 1). There is also a strong connection between some of these metabolic pathways and the metabolism of „one carbon" donors like S-adenosyl methionine (SAM) and $N^{5}$-methyl tetrahydrofolate ( $N^{5}$-methyl THF).

Demethylation of the essential, diet-derived amino acid methionine (L-Met) represents the only reaction through which Hcy is synthesized in humans. This conversion involves two enzymes, SAM synthetase/L-Met adenosyltransferase (EC 2.5.1.6) and S-adenosyl homocysteine $(\mathrm{SAH})$ hydrolase (EC 3.3.1.1). SAM synthetase activates L-Met in a reaction with ATP leading to SAM synthesis. SAM is used as a methyl donor in a variety of cellular biosyntheses (i.e., creatine, epinephrine, carnitine, phospholipids, proteins, nucleic acids and polyamines). Demethylation of SAM during the synthesis of the aforementioned compounds generates $\mathrm{SAH}$, which undergoes hydrolysis mediated by $\mathrm{SAH}$ hydrolase. Despite its reversibility, the latter reaction is responsible for $\mathrm{SAH}$ hydrolysis in vivo, due to the rapid removal of its two products. One consequence of an increased intracellular Hcy concentration is the accumulation of SAH through the reverse reaction catalyzed by SAH hydrolase. When present in excess, SAH acts as an inhibitor for SAM-dependent methylation reactions (Cantoni, 1985).

Resynthesis of L-Met from Hcy occurs via two reactions catalyzed by methionine synthase (EC 2.1.1.13) and betaine-Hcy methyltransferase (EC 2.1.1.5). Methionine synthase is one of the two enzymes that use vitamin $\mathrm{B}_{12}$ as coenzyme. The second substrate required by methionine synthase is $N^{5}$-methyl THF. The reaction catalyzed by this enzyme sets a link between Hcy and "one carbon" units" metabolism (Castro et al., 2006). N5-Methyl THF is synthesized from $N^{5,10}$-methylene THF through a reaction catalyzed by $N^{5,10}$-methylene THF reductase (MTHFR) (EC 1.1.1.68). This reaction requires NADH, being regulated by SAM and $\mathrm{SAH}$ as a negative and positive regulator, respectively.

Hcy is also the source of a highly reactive compound, Hcy-thiolactone. The synthesis of Hcy-thiolactone is associated with the misactivation of Hcy by the methionyltRNA synthetase (Jakubowski, 1997; Jakubowski, 2008a).

Liver, kidney and lens cells have the ability to convert Hcy to L-Met through a $\mathrm{B}_{12}$-independent reaction catalyzed by betaine-Hcy $S$-methyltransferase (BHMT) (EC

e-mail: manolescub@yahoo.fr

Abbreviations: BHMT, betaine-Hcy S-methyltransferase; Hcy, homocysteine; HDL, high density lipoprotein; LDL, low density lipoprotein; PON, paraoxonase; tHyc, total homocysteine 


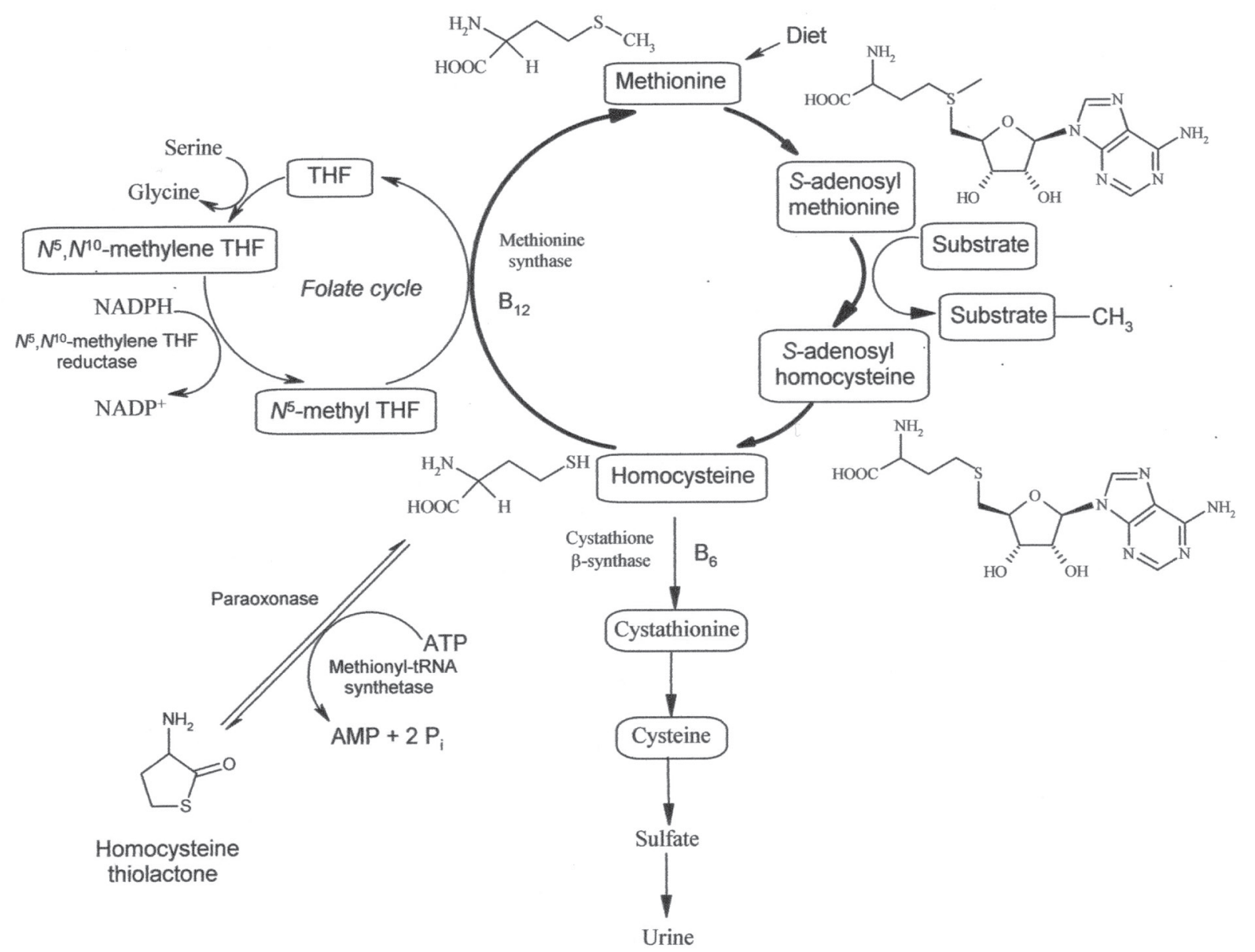

Figure 1. Schematic overview of homocysteine metabolism and its relationship with folic acid and vitamins $\mathrm{B}_{6}$ and $\mathrm{B}_{12}$ (modified from Lentz \& Haynes, 2004)

Table 1. Methods in use for total plasma homocysteine assay

\begin{tabular}{|c|c|c|}
\hline Method & Observations & References \\
\hline \multirow[t]{4}{*}{ Chromatography } & Liquid chromatography assays & \\
\hline & $\begin{array}{l}\text { HPLC, fluorescence detection } \\
\text { HPLC, UV spectrophotometric detection } \\
\text { HPLC, colorimetric detection } \\
\text { HPLC, electrochemical detection } \\
\text { LC-MS/MS }\end{array}$ & $\begin{array}{l}\text { (Sawula et al., 2008; Dai et } \\
\text { al., 2002) } \\
\text { (Glowacki \& Bald, 2009) } \\
\text { (Badiou et al., 2009) } \\
\text { (Zhang \& Pfeiffer, 2004) } \\
\text { (Kuhn et al., 2006) }\end{array}$ \\
\hline & Gas chromatography assays & \\
\hline & $\begin{array}{l}\text { GC-MS, electron ionization mode } \\
\text { GC-MS, flame photometric detection }\end{array}$ & $\begin{array}{l}\text { (Windelberg et al., 2005) } \\
\text { (Kataoka et al., 1995) }\end{array}$ \\
\hline Enzymatic assays & $\begin{array}{l}\text { assay using cystathionine } \beta \text {-synthase } \\
\text { assay using methionine } \gamma \text {-lyase from E. coli } \\
\text { assay using coupled enzymatic reactions (cystathionine } \beta \text {-lyase, lactate } \\
\text { dehydrogenase) } \\
\text { homocysteine } \alpha_{1} \gamma \text {-lyase releases } \mathrm{H}_{2} \mathrm{~S} \text { which is converted to a fluorescent } \\
\text { chromophore through reaction with } \mathrm{N}, \mathrm{N} \text {-dibutyl phenylene diamine }\end{array}$ & $\begin{array}{l}\text { (Martens et al., 2008) } \\
\text { (Chan et al., 2005) } \\
\text { (Roberts \& Roberts, 2004) } \\
\text { (Tan \& Hoffman, 2008) }\end{array}$ \\
\hline Combined assays & $\begin{array}{l}\text { conversion of Hcy to SAH followed by binding of SAH to a monoclonal } \\
\text { anti-SAH antibody: } \\
\text { fluorescence detection (Abbott ImxTM), } \\
\text { colorimetric detection using a second antibody coupled with peroxidase } \\
\text { (Bio-Rad EIA) }\end{array}$ & $\begin{array}{l}\text { (Donnelly \& Pronovost, 2000) } \\
\text { (Frantzen et al., 1998) }\end{array}$ \\
\hline Capillary electrophoresis & assay using laser induced fluorimetric detection & (Bayle et al., 2002) \\
\hline Chemosensors & $\begin{array}{l}\text { complex of Ir (III); color change from orange to yellow; luminescence chan- } \\
\text { ge from deep red to green, } \\
\text { complex of Pt (II); luminescence change from green to orange }\end{array}$ & $\begin{array}{l}\text { (Chen et al., 2007) } \\
\text { (Huang et al., 2009) }\end{array}$ \\
\hline
\end{tabular}


Table 2. Methods in use for the assessment of Hcy-thiolactone in different biological samples (modified from Jakubowski, 2006)

\begin{tabular}{llll}
\hline Method & Detection system & Characteristics of the method & Reference \\
\hline HPLC & UV & cation exchange/reverse phase & (Jakubowski, 2002b) \\
& fluorescence & cation exchange \\
& fluorivatization with OPA & (Chwatko \& Jakubowski, 2005) \\
& & reverse phase & (Mukai et al., 2002) \\
GC/MS & negative chemical ionization & derivatization with heptafluorobutyric anhydride & (Daneshvar et al., 2003) \\
\hline
\end{tabular}

OPA, o-phthalaldehyde

2.1.1.5) (Purohit et al., 2007). This reaction requires dietary betain or betain synthesized from dietary or endogenous choline (Stipanuk, 2004). Central nervous system lacks BHMT, being thus dependent on folate and vitamin $B_{12}$ for the conversion of Hcy to L-Met (Sunden et al., 1997).

The main disposal pathway of Hcy is its transsulfuration to L-Cys. This process takes place primarily in the liver, kidney, small intestine and pancreas. The first reaction is a condensation between Hcy and L-Ser leading to cystathionine which is further hydrolyzed to L-Cys and $\alpha$-ketobutyrate. These two reactions are catalyzed by the $\mathrm{B}_{6}$-dependent enzymes cystathionine- $\beta$-synthase (EC 4.2.1.22) and cystathionine- $\gamma$-lyase (EC 4.4.1.1), respectively. $\alpha$-Ketobutyrate undergoes oxidative decarboxylation to propionyl $\sim \mathrm{CoA}$, which is converted to succinyl CoA entering in the Krebs cycle. The transsulfuration pathway is responsible for both L-Met catabolism and sulfur atom transfer from L-Met to L-Ser, yielding L-Cys. L-Cys is a precursor for the synthesis of proteins, coenzyme A, and glutathione. Further catabolism of L-Cys gives rise to taurine and inorganic sulfate, both excreted through urine.

In conclusion, Hcy is central for some metabolic pathways: (i) resynthesis of $\mathrm{SAH}$ through reversal of $\mathrm{SAH}$ hydrolysis, (ii) remethylation to L-Met, and (iii) conversion to cystathionine.

\section{ASSESSMENT OF HOMOCYSTEINE AND HCY-THIOLACTONE IN BIOLOGICAL SAMPLES}

There are several species of plasma Hcy: (i) free Hcy, (ii) protein-bound Hcy (S-linked, and N-linked), (iii) oxidized forms, and (iv) Hcy-thiolactone (Syardal et al., 1986; Jakubowski, 2002a; 2008b). Under physiological conditions, less than $1 \%$ of total Hcy is present in a free reduced form. About $10-20 \%$ of total Hcy is present in different oxidized forms such as Hcy-Cys and homocystine, the Hcy dimer. The great majority (80-90\%) of plasma Hcy is N-linked and S- linked to serum albumin and $\gamma$-globulins (Jakubowski, 2002a).

Total plasma Hcy (tHcy) is defined as the pool of free homocysteine, homocystine, Hcy-S-S-Cys disulfide, as well as protein $\mathrm{N}$ - and S-linked Hcy. Total Hcy is used as a predictive risk factor for cardiovascular events, the post stroke evolution, screening for inborn errors of methionine metabolism, and as a supplementary test for vitamin $\mathrm{B}_{12}$ deficiency.

Hcy can be assessed in blood collected in either the fasting or nonfasting state. A standard dinner (about $50 \mathrm{~g}$ protein content) induces a 1.15-fold increase of plasma Hcy concentration (Guttormsen et al., 2004). Total Hcy concentration can be assessed in both plasma and serum samples, despite the fact that the latter give slightly higher values (Rasmussen \& Moller, 2000). Plasma has to be isolated very quickly to avoid Hcy leakage from erythrocytes and leukocytes or else blood samples should be treated with a preservative (i.e., sodium fluoride, 3-deazaadenosine, citric acid) (Salazar et al., 1999; Hansrani \& Stansby, 2007), albeit preservatives may influence the assay of total Hcy (Refsum et al., 2004).

Assessment of total Hcy concentration requires pretreatment of samples with a reducing agent (i.e., sodium borohydride, dithioerythritol, tris(2-carboxyethyl)phosphine) to reduce all disulfide bonds involving Hcy. This treatment does not release the $\mathrm{N}$-linked Hcy, i.e. Hcy residues bound to $\varepsilon$-amino groups of protein lysine residues. This can be achieved only by protein hydrolysis in an acidic environment and at high temperature (Jakubowski, 2008b).

The methods used to assess Hcy level in different biological samples can be classified into chromatographic methods, enzymatic assays, and combined assays (enzymatic reaction followed by an immunoassay) (Refsum et al., 2004). Plasma tHcy concentration can also be assessed through capillary electrophoresis with a suitable detection system. Very recently, assays based on addition of transition-metal complexes to carbonyl groups were developed (Chen et al., 2007; Hung et al., 2009). Most of the chromatographic methods require sample deri-

Table 3. Methods in use for the assessment of protein-linked Hcy

\begin{tabular}{llll}
\hline Method & Derivatization agent & Detection system & Reference \\
\hline HPLC $\left(C_{18}\right.$ RP) & 2-chloro-1-methylpyridinium iodide & UV & (Bald et al., 2000) \\
HPLC $\left(C_{18}\right.$ RP) & 4-fluoro-7-sulfamoyl-benzofurazan & Fluorescence & (Uji et al., 2002) \\
HPLC (CE) & - & UV multiwavelength & (Jakubowski, 2002a) \\
HPLC (CE) & o-phthaldialdehyde & Fluorescence & (Jakubowski, 2008b) \\
HPLC & 7-fluoro-1,3-benzoxadiazole-4-sulfonate & Fluorescence & (Hortin et al., 2006) \\
HPLC & 7-fluorobenzo-2-oxa-1,3-diazole-4-sulfonate & Fluorescence & (Perna et al., 2006) \\
\hline
\end{tabular}

$R P$, reverse phase; $C E$, cation exchange 
Table 4. Causes of increased plasma tHcy (modified from Lentz \& Haynes, 2004; Brosnan et al., 2004; Pezzini et al., 2007; Bottiglieri, 2005)

\begin{tabular}{|c|c|}
\hline Plasma Hcy concentration & Deficiencies \\
\hline $\begin{array}{l}\text { Severe hyperhomocysteine- } \\
\text { mia } \\
(>100 \mu \mathrm{M})\end{array}$ & $\begin{array}{l}\text { genetic deficiency of cystathionine } \beta \text {-synthase }(\mathrm{Hcy} \approx 500 \mu \mathrm{mol} / \mathrm{L}) \\
\text { genetic deficiency of } N^{5,10} \text {-methylene tetrahydrofolate reductase } \\
\text { genetic defect impairing vitamin } B_{12} \text { absorption }\end{array}$ \\
\hline $\begin{array}{l}\text { Moderate hyperhomocyste- } \\
\text { inemia } \\
(30-100 \mu \mathrm{M})\end{array}$ & $\begin{array}{l}\text { dietary moderate vitamin } B_{12} \text { deficiency } \\
\text { dietary severe folate deficiency } \\
\text { genetic deficiency of } N^{5,10} \text {-methylene tetrahydrofolate reductase } \\
\text { renal failure } \\
\text { atrophic gastritis } \\
\text { medication (nitric oxide, L-DOPA) }\end{array}$ \\
\hline $\begin{array}{l}\text { Mild hyperhomocysteinemia } \\
(10-30 \mu \mathrm{M})\end{array}$ & $\begin{array}{l}\text { genetic deficiency of } \mathrm{N}^{5,10-m e t h y l e n e ~ t e t r a h y d r o f o l a t e ~ r e d u c t a s e ~(p o l y m o r p h i s m ~ C 677 T) ~} \\
\text { dietary vitamin } \mathrm{B}_{6} \text { deficiency } \\
\text { diabetes, hypothyroidism, malignancies, atrophic gastritis, renal transplantation } \\
\text { daily habits (smoking, alcohol and coffee consumption) } \\
\text { medication (niacin, fibrates, methotrexate, isoniazid, levodopa, theophylline, phenytoin, nitric oxide, } \\
\text { trimethoprim, anticonvulsants, metformine, azauridine, androgens, cyclosporin A) }\end{array}$ \\
\hline
\end{tabular}

vatization. The derivatization is made either before the passage of the sample through the column, or after this step. The derivatization agents are classified depending on the detection system used: (1) 2-chloro-1-methylpyridinium iodide (UV spectrophotometric detection), (2) ninhydrin, 2-chloro-1-methylquinolinium tetrafluoroborate (visible spectrophotometric detection), (3) monobromobimane, o-phthaldialdehyde, halogensulfonyl benzofurazans, iodoacetamidofluoresceine (spectrofluorimetric detection) (Bald et al., 2000; Ubbink, 2000; Fermo \& Paroni, 2000; Bayle et al., 2002; Glowacki \& Bald, 2009; Ichinose et al., 2009). Alternatively, an electrochemical detection system, not needing derivatization, can be used (Martin et al., 1999; Houze et al., 2006). Table 1 summarizes aspects concerning the methods used to assess total plasma Hcy concentration. Different methods are available for the assessment of Hcy-thiolactone in biological samples (plasma, urine) (Table 2). The assessment of protein-linked Hcy requires also a different approach (Table 3).

\section{DETERMINANTS OF PLASMA tHcy CONCENTRATIONS}

Plasma tHcy levels are influenced by genetic, physiologic (age, sex) and lifestyle factors, and various pathologic conditions (De Bree et al., 2002). The physiological range of plasma total Hcy is defined as the 2.5th to 97.5th percentile interval for the analyzed group (Lentz \& Haynes, 2004). This corresponds to a lower limit of $5 \mu \mathrm{M}$, while the upper limit varies considerably between laboratories and different populations. As in the case of other biochemical parameters, for Hcy also its own reference interval should be established taking into account the influence of different non-modifiable and modifiable factors. The relationship between different factors and plasma Hcy concentration is beyond the aim of this review as there are several excellent reviews dealing with this subject (De Bree et al., 2002; Pezzini et al., 2007).

\section{HYPERHOMOCYSTEINEMIA}

The term "hyperhomocysteinemia" does not define a pathological condition. It is rather used to describe a biochemical abnormality which can be a direct consequence of various pathological conditions. Plasma Hcy concentration could represent a gradual indicator of the risk for cardiovascular disease (Lentz \& Haynes, 2004). Thus, every increase of $2.5 \mu \mathrm{M}$ in plasma Hcy can be associated with an increase of stroke risk of about $20 \%$ (Clarke et al., 2002). Moreover, plasma tHcy levels above $20 \mu \mathrm{M}$ are associated with a nine-fold increase of the myocardial infarction and stroke risk when compared to concentrations below $9 \mu \mathrm{M}$ (Nygard et al., 1997).

Certain drugs (adenosine analogues, D-penicillamine, $\mathrm{N}$-acetylcysteine, estrogens, tamoxifen, betaine) decrease blood Hcy concentration through different mechanisms (i.e., remethylation stimulation, inhibition of SAH hydrolase activity) (Pezzini et al., 2007).

\section{MECHANISMS OF HOMOCYSTEINE TOXICITY}

Over the years, several theories concerning the toxicity of Hcy have been elaborated, but despite the efforts, none does to completely explain the toxicity of this compound.

One of the first hypotheses suggested that hydrogen peroxide formed as a byproduct in metal ion-catalyzed redox reactions involving the thiol group of Hcy was responsible for the toxicity of this compound. The major drawback of this hypothesis was the fact that L-Cys is not a risk factor for vascular disease, despite its 20- to 30 -fold higher concentration than that of Hcy Jacobsen, 2000). Moreover, the amount of hydrogen peroxide produced with the participation of Hcy is very low and its formation is possible only in the presence of transition metal ions as catalysts (Zappacosta et al., 2001).

A more recent theory suggests that Hcy toxicity is a consequence of covalent binding of this compound to proteins, thus modifying their functions (Fig. 2). The process is called homocysteinylation and can be either Shomocysteinylation, when Hcy binds through a disulfide bond to a free protein sulfhydryl residue, or N-homocysteinylation, when Hcy binds through an amide bond to an $\varepsilon$ amino group of a protein lysine residue.

Hcy binds through a disulfide bond to fibronectin, annexin II, and intracellular metallothionein, among other intracellular proteins (Majors et al., 2002; Hajjar et al., 1998; Barbato et al., 2007). S-Homocysteinylation of the first two proteins results in inhibition of fibronectin-fibrin interaction and annexin II-tissue plasminogen activator interaction, respectively. One of the plasma proteins that is subject to modification through homocysteinylation is transthyretin (Hanyu et al., 2009). This modification could be responsible for the denaturation and deposition of this protein, as seen in familial amyloid polyneuropathy. Homocysteinylation of metallothionein 


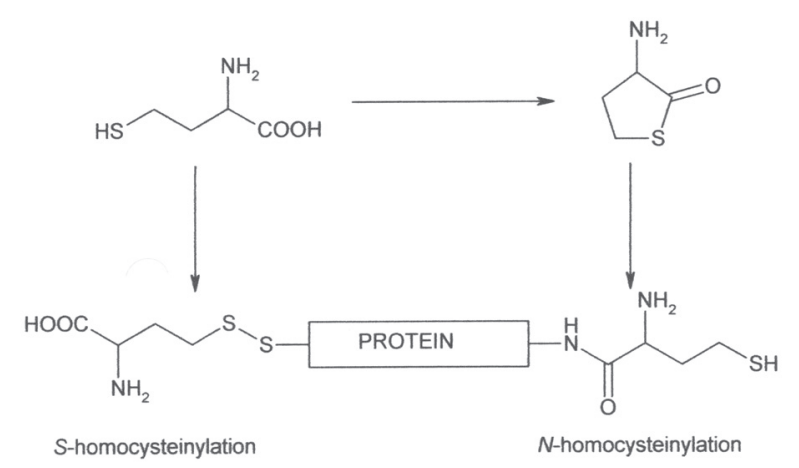

Figure 2. S- and $\mathrm{N}$-homocysteinylation of proteins by homocysteine and homocysteine thiolactone, respectively

could be responsible for redox imbalance. Generally, Shomocysteinylation alters the function of biomolecules through: (i) inactivation of potentially active free thiol groups, and (ii) alteration of redox potential of a protein molecule.

N-Homocysteinylation is a consequence of the high reactivity of Hcy-thiolactone towards free amino functions, especially the $\varepsilon$ amino group of lysine residues from proteins (Jakubowski, 1997; 1999). In vivo, Нcythiolactone targets and modifies blood albumin, hemoglobin, immunoglobulins, LDL, HDL, transferrin, antitrypsin, and fibrinogen (Jakubowski, 2002a; 2008a). Also, Hcy-thiolactone acts as an inhibitor of $\mathrm{Na}^{+} / \mathrm{K}^{+}$-ATP-ase from the cortex, hippocampus, and brain stem of rats, affecting the membrane potential with deleterious effects for neurons (Rasic-Markovic et al., 2009).

Elevated plasma levels of both Hcy-thiolactone and proteins modified through $\mathrm{N}$-homocysteinylation are a direct consequence of either genetic defects in Hcy metabolism or a methionine-rich diet (Brosnan et al., 2004; Jakubowski et al., 2009). Spiroski et al. (2008) showed that methylenetetrahydrofolate reductase (MTHFR-677 and MTHFR-1298) genotypes and haplotypes can be correlated with increased tHcy plasma levels in patients with occlusive artery disease and deep venous thrombosis.

Plasma concentration of proteins modified through $\mathrm{N}$-homocysteinylation ranges between 0.35 and $0.51 \mu \mathrm{M}$ (Jakubowski et al., 2008). However, in pathological conditions the plasma concentration of these proteins ranges from a two-fold elevation (renal failure) up to a 24-30fold elevation (genetic defects of MTHFR and cystathionine $\beta$-synthase) (Perna et al., 2006).

Generally, N-homocysteinylation alters the function of proteins through (i) introduction of new free thiol groups, and (ii) inactivation of free amino groups, affecting the overall redox potential of proteins. Moreover, it has been found that proteins modified through $\mathrm{N}$-homocysteinylation can act as neoantigens, triggering activation of the inflammatory response, a key component in atherogenesis, atherotrombosis and stroke etiology (Undas et al., 2004). Also, these neoantigens induce an autoimmune response, the concentration of autoantibodies being higher in some pathological conditions (i.e., cerebrovascular disease, renal failure) than in normal subjects (Undas et al., 2007). This situation could explain, at least in part, the association of hyperhomocysteinemia with certain stroke subtypes such as small vessel disease, large vessel disease, and primary intracerebral hemorrhage (Eikelboom et al., 2000; Li et al., 2003; Perini et al., 2005). It has been hypothesized that N-homocysteinylated proteins ex- posed at the luminal face of endothelial cells are recognized by specific antibodies, the neoantigen-autoantibody interaction leading to activation of circulating macrophages, which become responsible for repeated vascular endothelium damage. Moreover, Hcy-thiolactone impairs the ability of the vascular endothelium to regenerate itself through direct inhibition of lysyl oxidase, which is responsible for the correct cross-linking of collagen and elastin in the arterial wall (Liu et al., 1997; Raposo et al., 2004).

One mechanism of protection from N-homocysteinylation is through the action of the enzyme called paraoxonase 1 (PON1, EC 3.1.8.1). PON1, a calciumdependent enzyme synthesized by the liver, is a major component of plasma HDL particles, responsible for the antioxidant protection of LDL particles. For PON1, three enzymatic activities have been described: paraoxonase, arylesterase and lactonase (Billecke et al., 2000). The paraoxonase activity is the ability of the enzyme to hydrolyze different organophosphate compounds (paraoxon, diazoxon, soman, sarin). The arylesterase activity is evaluated using phenylacetate as a substrate, while lactonase activity is evaluated using different aromatic lactones (i.e., dihydrocoumarin, 2-coumaranone, homogentisic acid lactone). It is believed that under physiological conditions, the lactonase activity prevails, one of the enzyme's in vivo substrate being Hcy-thiolactone. PON1 has the ability to hydrolyze Hcy-thiolactone, this activity being a major determinant of plasma N-homocysteinylated protein concentration (Jakubowski, 2000; Perla-Kajan \& Jakubowski, 2010). It was found that both in vitro and in vivo the lactonase activity of PON1 negatively correlates with $\mathrm{N}$-homocysteinylated protein concentration. Impairment of the PON1 Hcy-thiolactonase activity is responsible, at least in part, for the severity of cardiovascular disease in subjects with coronary artery disease (Koubaa et al., 2009). Thus, due to the lactonase/Hcythiolactonase activity of PON1, HDL particles could prevent post-translational modification of LDL apoproteins through N-homocysteinylation.

Another report suggests that Hcy exerts its toxicity through induction of endoplasmic reticulum (ER) stress. Increased intracellular Hcy concentration is associated with both alteration of redox balance and post-translational protein modifications through $\mathrm{N}$ - and S-homocysteinylation. ER is very sensitive to intracellular Hcy or Hcy metabolites' accumulation due to a local redox imbalance and $\mathrm{Ca}^{2+}$ release. As a consequence of the local redox imbalance, proteins misfold, initiating an ER stress response (Chigurupati et al., 2009) that triggers the expression of different chaperone proteins, growth arrest and apoptosis (Outinen et al., 1999; Zhang et al., 2001). Intracytoplasmic accumulation of calcium has deleterious effects leading to excessive ATP consumption as cells try to pump $\mathrm{Ca}^{2+}$ out, and also activates a series of enzymes such as calpain, phospholipase $A_{2}$, nitric oxide synthase etc.

The effect of high plasma Hcy concentration on gene expression is dual. Transcription of the gene coding for glutathione peroxidase-1 (GPx1) is down regulated by Hcy (Lubos et al., 2007). Moreover, Hcy downregulates endothelial heparane sulfate with subsequent decrease of extracellular membrane-bound superoxide dismutase present at the luminal face of the endothelium and as a consequence, the endothelium becomes exposed to deleterious effects of $\mathrm{O}_{2}^{\bullet-}$ (Yamamoto et al., 2000). Other studies suggest that Hcy induces the expression of superoxide dismutase in endothelial cells leading to con- 
sumption of $\mathrm{NO}^{\bullet}$ and thus impairing endothelial vasorelaxation (Hucks et al., 2004).

\section{HOMOCYSTEINE AS AN AGGRESSION FACTOR AGAINST THE ENDOTHELIUM}

Hcy is an important endothelial aggression factor promoting endothelial dysfunction through different mechanisms, leading to atherosclerotic plaque formation. Hcy (i) inhibits the growth of endothelial cells, (ii) induces an imbalance between $\mathrm{O}^{\bullet-}$ and $\mathrm{NO} \bullet$ with deleterious effects on the vascular physiology, (iii) induces the expression of different adhesion molecules, and (iv) promotes the formation of modified LDL particles, which are important players in the etiology of atherosclerotic plaque formation (Fig. 3).

Hcy activates, through different pathways, NAD $(\mathrm{P}) \mathrm{H}$ oxidase and xanthine oxidase, two important pro-oxidant enzymes that generate $\mathrm{O}_{2}{ }^{\bullet-}$ in the endothelial cells.

Using human umbilical vein endothelial cells (HUVEC) it was found that Hcy activates the NADPH oxidase complex through plasma membrane translocation of the cytoplasmic subunit p47phox (Carluccio et al., 2007). The fact that Hcy-dependent activation of $\mathrm{NAD}(\mathrm{P}) \mathrm{H}$ oxidase plays a central role in endothelial redox imbalance was proved by the ability of the $\mathrm{NAD}(\mathrm{P}) \mathrm{H}$ oxidase inhibitor apocynin which restores both $\mathrm{O}_{2}{ }^{--}$concentration and vascular tonus to control Hcy levels in hyperhomocysteinemic rats (Edirimanne et al., 2007).

Another important source of $\mathrm{O}_{2}{ }^{\bullet-}$ in the vascular endothelium is xanthine oxidase (Bagi et al., 2002). Administration of the xanthine oxidase inhibitor oxypurinol prevented flow-induced constriction of arterioles from rats with hyperhomocysteinemia.

$\mathrm{O}_{2}^{\bullet-}$ can interact with $\mathrm{NO}^{\bullet}$, synthesized by the constitutive endothelial nitric oxide synthase (eNOS), producing the peroxynitrite anion $\left(\mathrm{ONOO}^{-}\right)$. Consumption of $\mathrm{NO} \bullet$ through this reaction is responsible for alteration of the vascular tonus. Moreover, $\mathrm{ONOO}^{-}$is responsible for the induction of thromboxane $A_{2}$ synthesis in both endothelial cells and platelets, leading to vasoconstriction (Ungvari et al., 2000; Bagi et al., 2002). This is probably achieved through peroxynitrite-dependent inactivation of prostaglandin $\mathrm{I}_{2}$ synthase, arachidonic acid becoming thus available for thromboxane $A_{2}$ synthesis (Zou et al., 1999).

Free radicals induce the conversion of tetrahydrobiopterin $\left(\mathrm{BH}_{4}\right)$, one of the eNOS cofactors, to trihydrobiopterin $\left(\mathrm{BH}_{3}{ }^{\circ}\right)$ leading to eNOS uncoupling (Patel et al., 2002). There is evidence for a direct involvement of Hcy in free radical-induced eNOS uncoupling (Topal et al., 2004). Decreased bioavailability of $\mathrm{BH}_{4}$ for eNOS changes the activity of this enzyme from $\mathrm{NO}^{\bullet}$ to $\mathrm{O}_{2}^{\bullet-}$ production. Moreover, in animal models for hyperhomocysteinemia, administration of an $\mathrm{O}_{2}^{\bullet-}$ scavenger (e.g., superoxide dismutase, 4,5-dihydroxybenzene 1,3-disulfonate) reverses endothelial dysfunction, suggesting that at least in part, the Hcy-dependent endothelial dysfunction is mediated by $\mathrm{O}_{2}{ }^{\bullet-}$ (Weiss et al., 2003).

The plasma concentration of ADMA ( $N^{\omega}, N^{\omega}$-dimethyl$\mathrm{L}$-arginine), an endogenous inhibitor of NOS isoforms, is controlled by two dimethylarginine dimethylaminohydrolases (DDAH-1 and DDAH-2), both hydrolyzing ADMA to L-citrulline and dimethylamine. The Hcy-NO• adduct is a selective inhibitor for the human DDAH-1, preventing ADMA hydrolysis and leading to inhibition of NOS enzymes (Hong \& Fast, 2007).

Moreover, Hcy-induced overproduction of $\mathrm{O}_{2}^{\bullet-}$ is responsible, at least in part, for the activation of the nuclear factor $x \mathrm{~B}(\mathrm{NF}-x \mathrm{~B})$, a key regulator of gene expression (Au-Yeung et al., 2004). NF- $x \mathrm{~B}$ induces the expression of genes coding for pro-inflammatory proteins like monocyte chemoatractant protein-1 (MCP-1), vascular cell adhesion molecule-1 (VCAM-1), intercellular adhesion molecule-1 (ICAM-1), E-selectin, and receptor for advanced glycation end products (RAGE) in endothelial cells (Poddar et al., 2001; Hofmann et al., 2001; Carluccio et al., 2007; Hwang et al., 2008). Thus, Hcy enhances monocyte binding to vascular endothelium, a key event in the process of atherosclerotic plaque formation. In vitro studies using endothelial cells, monocytes and macrophages exposed to different concentrations of Hcy for different times, have revealed different degrees of induc-

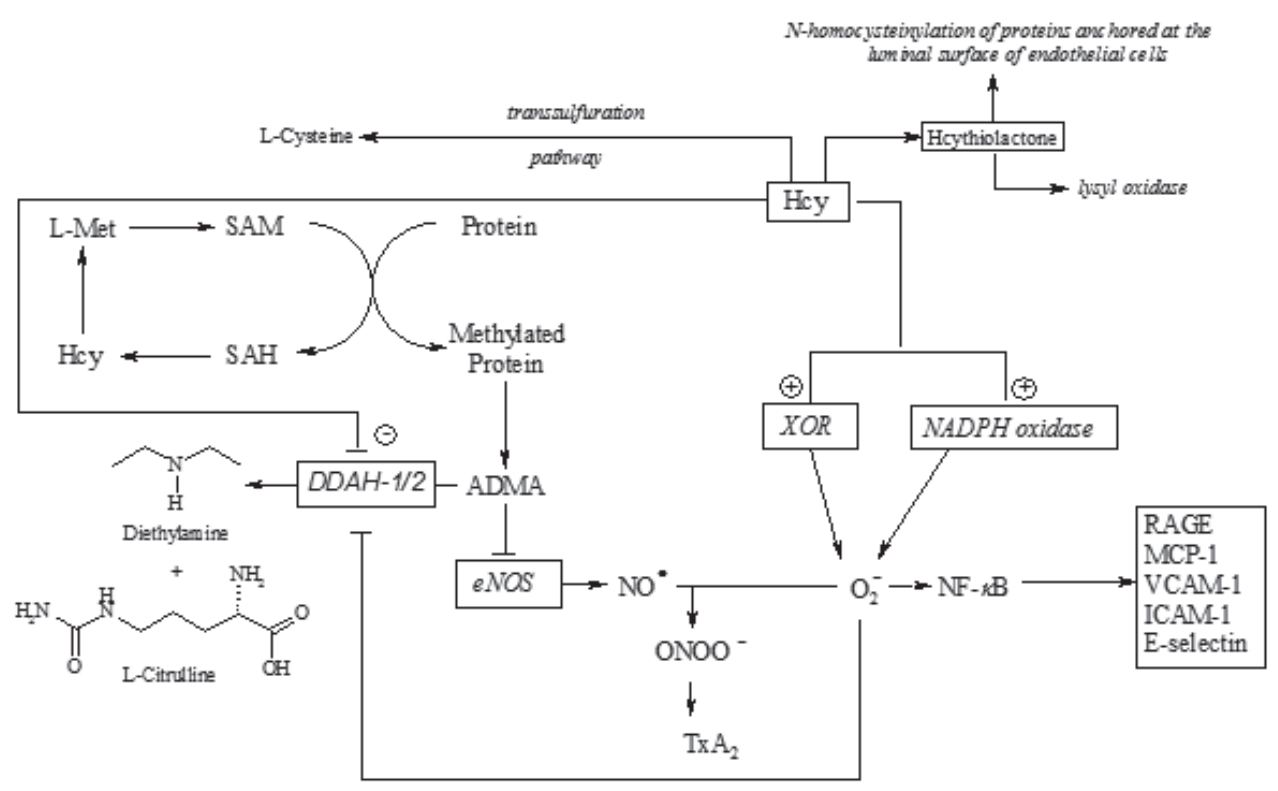

Figure 3. Some of the biological effects of Hcy at endothelial level. 
tion of pro-inflammatory cytokines (MCP-1, IL-1 $\beta$, IL-6, IL-8, and TNF- $\alpha$ ) (Dalal et al., 2003; Zeng et al., 2003). Moreover, Hcy induces selective differentiation of Ly$6 C^{\text {hi }}$ and Ly-6C mid inflammatory monocyte subsets, followed by their retention in atherosclerotic lesions (Zhang et al., 2009). Also, the interaction between Hcy-activated endothelial cells and monocytes leads to increased expression of CD36 scavenger receptor by monocytes (Thampi et al., 2008). This process could represent another link between hyperhomocysteinemia and atherosclerotic plaque formation and progression.

A metabolic peculiarity of endothelial cells that renders them very susceptible to Hcy toxicity is their inability to metabolize Hcy through the transsulfuration pathway (Jacobsen et al., 1995). Hcy alters gene expression in endothelial cells through different mechanisms: (i) inhibition of the transcription of the cyclin $A$ gene, (ii) inhibition of cyclin A messenger RNA expression, and (iii) transcriptional repression of the gene coding for FGF2 (fibroblast growth factor 2) (Wang et al., 2002; Jamaluddin et al., 2007; Chang et al., 2008). These effects are the result of alteration of the methylation patterns of the promoters of the gyclin $A$ and FGF2 genes.

In vitro studies suggested an additional mechanism for Hcy toxicity through post-translational modifications of LDL particles. Hcy promotes both oxidation of LDL particles by ceruloplasmine's oxidase activity, and nitration (Exner et al., 2002; Griffiths et al., 2006). Modified LDL particles are highly pro-aterogenic promoting the formation of foam cells through uptake by scavenger receptors expressed by monocytes.

Finally, another mechanism that in conjunction with the aggression effect upon endothelium could explain the proatherosclerotic effect of Hcy and Hcy-thiolactone is the ability of the latter compound to covalently modify serum fibrinogen. It was found that clots containing N-homocysteinylated fibrinogen are more resistant to fibrinolysis, leading to increased risk of thrombotic events (Jakubowski et al., 2008; 2009).

These processes could provide an important link between hyperhomocysteinemia and atherosclerotic aggression on endothelium.

\section{HOMOCYSTEINE AS A NEUROTOXIN}

Both in vitro and in vivo studies have indicated that Hcy exerts neurotoxic effects inducing neuronal damage and cell loss through excitotoxicity and apoptosis. This could be, at least in part, a direct consequence of the inability of cerebral tissue to metabolize Hcy through the betaine and transsulfuration pathways, favoring Hcy accumulation in the nervous system (Finkelstein, 1998).

Stroke patients are a particular risk group as disruption of the blood-brain barrier exposes nervous tissue to plasma Hcy concentration for prolonged periods (Lindgren et al., 1995). Moreover, it was found that Hcy itself is able to induce blood-brain barrier (BBB) disruption (Kamath et al., 2006). The disruption of BBB is the consequence of at least two different processes. On the one hand, Hcy induces an imbalance between the activity of matrix metalloproteinase 9 (MMP-9) and the level of tissue inhibitor of metalloproteinase-4 (TIMP-4), through increasing MMP-9 activity and decreasing TIMP-4 level (Moshal et al., 2006; Tyagi et al., 2009). As a consequence, MMP-9 acts upon different components of the $\mathrm{BBB}$ leading to disruption of this structure. On the other hand, Hcy acts as an excitatory neurotransmitter through $\gamma$-aminobutyric acid (GABA) receptors A/B, leading to increased vascular permeability (Tyagi et al., 2005; 2007).

Hcy acts as an agonist for both group I and group III metabotropic glutamate receptors as well as for $N$ methyl-D-aspartate (NMDA) and $\alpha$-amino-3-hydroxy-5methyl-4-isoxazolepropionate (AMPA)/kainite ionotropic glutamate receptors (Boldyrev and Johnson, 2007; Bleich et al., 2004; Ho et al., 2002). Overstimulation of these receptors triggers cytoplasmic calcium pulses, overproduction of free radicals, and activation of caspases leading to apoptosis. Using spontaneously hypertensive strokeprone rats, it was found that exposure of nervous tissue to Hcy during stroke is followed by secretion of excitatory amino acids, i.e., glutamate and aspartate, which are responsible for further excitotoxic effects on neurons (Ganguly et al., 2008). Activation of neuronal ERK2 (extracellular signal-regulated kinase 2) is a direct consequence of Hcy-induced NMDA receptor stimulation (Poddar \& Paul, 2009). Also, after a transient activation of the pro-survival transcription factor CREB (cAMP response-element binding protein) by ERK2, CREB becomes inhibited, favoring neuronal apoptotic death.

Expression of NMDA receptor is not confined to neurons. Other cells, including endothelial cells from cerebral tissue, can express this receptor. Free radicals induce up-regulation of the NR1 subunit of the NMDA receptor, increasing the susceptibility of cerebral endothelial cells to excitatory amino acids, favoring BBB disruption (Betzen et al., 2009).

Another consequence of the nervous tissue exposure to Hcy is the activation of poly-ADP-ribose polymerase (PARP) in neurons leading to consumption of ATP and $\mathrm{NAD}^{+}$with deleterious effects upon energetic metabolism, followed by free radical production (Kruman et al., 2000). It was also found that Hcy is able to inhibit neuronal DDHA activity leading to accumulation of ADMA with subsequent inhibition of neuronal NOS (Selley, 2004).

Not only neuronal cells are subject to toxic effects of Hcy, but also microglia, which are brain-resident macrophages. Hcy promotes activation of these cells through induction of NAD(P)H oxidase (Zou et al., 2009). Also, in vivo studies indicated that Hcy exerts toxic effects on endothelial cells from cerebral vasculature through mechanisms previously presented (Dayal et al., 2004). Another consequence of hyperhomocysteinemia is represented by Hcy-induced toxic effect on endothelial progenitor cells (Alam et al., 2009). Exposure of these cells to high levels of Hcy is followed by induction of their apoptosis through caspase- 3 and -8 activation and cytochrome $c$ release from mitochondria.

\section{HOMOCYSTEINE, STROKE AND VITAMIN THERAPY}

Different clinical trials have recognized Hcy as an independent cardio- and cerebrovascular risk factor. One such trial enrolled 5661 monitored in time (Perry et al., 1995). During the follow-up period 141 cerebrovascular events (stroke) were recorded. Using a study group of 107 from among those that developed stroke and a control group of 118, it was found that the geometric mean of plasma Hcy concentration was significantly increased in the study group $(13.7 \mu \mathrm{M} v$ s. $11.9 \mu \mathrm{M}, P=0.004)$.

Due to the dependence of Hcy metabolism on folic acid and vitamins $B_{6}$ and $B_{12}$ it was suggested that administration of these vitamins could reduce plasma Hcy concentration, lowering the risk of stroke and stroke re- 
currence. Indeed, many trials have indicated that administration of folic acid and vitamins $B_{6}$ and $B_{12}$ decreased serum Hcy concentration. However, some of these studies failed to show a direct correlation between vitamin intake and lowered risk for cardio- and cerebrovascular events (Clarke et al., 2002). Some potential causes responsible for the lack of consensus between these trials could be (i) differences between study groups in respect to baseline Hcy concentrations, (ii) inclusion of patients from countries that do not have regulations regarding food enrichment with folic acid, (iii) trial period, (iv) composition of vitamin formulations, (v) gender distribution, and (vi) patients' medication. Also, patients' compliance is an important factor for the success of trials that investigate the impact of some drugs on the course of a pathological condition.

The VISP (Vitamin Intervention for Stroke Prevention) trial (double-blind, randomized, controlled study) showed no significant reduction in stroke recurrence between the group that received a low-dose vitamin formulation $\left(200 \mu \mathrm{g} \mathrm{B}, 6 \mu \mathrm{g} \mathrm{B} \mathrm{B}_{12}, 20 \mu \mathrm{g}\right.$ folic acid) and the group that received a high-dose vitamin formulation (25 $\mathrm{mg} \mathrm{B}_{6}, 0.4 \mathrm{~B}_{12}, 2.5 \mathrm{mg}$ folic acid) $(P=0.80)$. There was also a modest difference in the reduction of Hcy plasma level between the two groups $(2 \mu \mathrm{M})$ (Toole et al., 2004). One explanation for the failure of that study was the very low baseline level of plasma $B_{12}$ vitamin. Excluding the patients that received monthly vitamin $B_{12}$, the patients with high plasma vitamin $\mathrm{B}_{12}$ concentration ( $>637$ $\mathrm{pmol} / \mathrm{L}$ ) and those with renal failure generated a new group of 2155 persons. Statistical analysis performed with this new group indicated that stroke incidence in the new high-dose vitamin formulation group was almost $21 \%$ lower than in the other group, suggesting a beneficial role of high doses of vitamin $\mathrm{B}_{12}(P=0.049)$ (Spence et al., 2005). At the same time, it was noted that a better capacity of vitamin $\mathrm{B}_{12}$ absorption associated with the high-dose vitamin $\mathrm{B}_{12}$ therapy decreased the incidence of cerebrovascular events.

HOPE-2 (Heart Outcomes Prevention Evaluation 2) and NORVIT (Norwegian Vitamin) trials indicated a beneficial effect of folic acid and vitamins $\mathrm{B}_{6}$ and $\mathrm{B}_{12}$ on plasma Hcy concentration (Bønaa et al., 2006; Saposnik et al., 2009). One major difference between the HOPE-2 and NORVIT trials on the one hand and VISP trial on the other was their duration. The follow-up period for the first two studies was 5 years and 3.5 years, respectively, while the follow-up period for the VISP trial was 2 years.

The HOPE-2 trial indicated that the overall stroke incidence was lower in the vitamin group when compared to the placebo group $(P=0.03$, Saposnik et al., 2009). Also the incidence of the two main types of stroke was lower in the vitamin group when compared to the control group (ischemic stroke, 30.62\% vs. 37.98\%; hemorrhagic stroke, $3.1 \%$ vs. $3.87 \%$ ). By contrast, full recovery at day 7 or at discharge was more frequent, but not significantly, in the vitamin group (vitamin group vs. placebo group, $15.7 \%$ vs. $9.6 \%$ ). In the period $24 \mathrm{~h}$ from the moment of stroke onset there was no significant improvement of the neurological deficit between the two groups. The results of HOPE-2 trial indicated that vitamin therapy could be beneficial for some particular categories: persons younger than 70 years (untreated dyslipidemia, no medication for coagulopathies), patients with hyperhomocysteinemia, and people from countries where there is no regulation regarding food enrichment with folic acid.
Another conclusion of the VISP, HOPE-2 and NORVIT trials was that correction of vitamin $B_{12}$ status in the elderly, in conjunction with folic acid therapy, could decrease stroke risk.

A recent meta-analysis study of several prospective trials from 2007 until 2009 has offered some possible directions for future research in this area (Lee et al., 2010). It was found that Hcy-lowering therapy could be beneficial in patients with vascular disease in early stages. Also, such an approach could be more successful in men than in women. This study suggested that only clinical trials with follow-up periods of 3 years or more report decreased stroke incidence, probably because the biological effect only then becomes apparent.

The supplementation of grain products with folic acid was implemented mandatory by 1998 in the USA and Canada. If high homocysteine concentrations are an independent risk factor for stroke, one might expect a reduction in stroke mortality following folic acid fortification. Indeed, a recent population-based study showed that the decline in stroke mortality accelerated in 19982002 in nearly all population in the USA and Canada (Wang et al., 2007).

\section{CONCLUSIONS}

Despite the beneficial effects of vitamin therapy on plasma Hcy concentration, there are no unequivocal data regarding the impact of lowering Hcy level on the incidence and/or recurrence of cerebrovascular events. This situation could be solved by using larger population trials. Also, the trial period could be an important factor for the success of such studies, enabling the beneficial effects to become apparent. Stroke incidence and recurrence should be investigated in relation with gender, as men have higher incidence of cerebrovascular events than women, along with a plethora of secondary pathologies. Another issue that should be better addressed is the subclinical vitamin $\mathrm{B}_{12}$ deficiency that affects a large number of elderly people. Correction of vitamin $B_{12}$ status, along with administration of the other vitamins required for Hcy metabolism could lead to a decrease in the frequency of cerebrovascular events.

\section{Acknowledgements}

We thank Dr. Hieronim Jakubowski (Department of Microbiology and Molecular Genetics, UMDNJ-New Jersey, Medical School, Newark, USA, and Institute of Bioorganic Chemistry, Polish Academy of Sciences, Poznan, Poland) for helpful discussion and critical reading of the manuscript.

\section{REFERENCES}

Alam MM, Mohamed AA, Shuaib U, Wang C, Ghani U, Schwindt B, Todd KG, Shuaib A (2009) Homocysteine reduces endothelial progenitor cells in stroke patients through apoptosis. J Cerebr Blood F Met 29: 157-165.

Au-Yeung KKW, Woo CWH, Sung FL, Yip JCW, Siow YL (2004) Hyperhomocysteinemia activates nuclear factor- $x \mathrm{~B}$ in endothelial cells via oxidative stress. Circ Res 94: 28-36.

Badiou S, Bariolet S, Dupuy A-M, Sultan A, Avignon A, Cristol J-P (2009) A new DiaSys colorimetric assay for plasma homocysteine: application in diabetic patients. Ann Clin Lab Sci 39: 233-240.

Bagi Z, Ungvari Z, Koller A (2002) Xanthine oxidase - derived reactive oxygen species convert flow-induced arteriolar dilation to constriction in hyperhomocysteinemia: possible role of peroxynitrite. Arterioscl Throm Vas 22: 28-33. 
Bald E, Kaniowska E, Chwatko G, Glowacki R (2000) Liquid chromatographic assessment of total and protein-bound homocysteine in human plasma. Talanta 50: 1233-1243.

Barbato JC, Catanescu O, Murray K, DiBello PM, Jacobsen DW (2007) Targeting of metallothionein by L-homocysteine: a novel mechanism for distuption of zinc and redox homeostasis. Arterioscl Throm Vas 27: 49-54.

Bayle C, Issac C, Salvayre R, Couderc F, Causse E (2002) Assay of total homocysteine and other thiols by capillary electrophoresis and laser-induced fluorescence detection. II. Pre-analytical and analytical conditions. I Chromatogr A 979: 255-260.

Betzen C, White R, Zehendner CM, Pietrowski E, Bender B, Luhmann HJ, Kuhlmann CRW (2009) Oxidative stress upregulates the NMDA receptor on cardiovascular endothelium. Free Radical Biol Med 47: 1212-1220.

Billecke S, Draganov D, Counsell R, Stetson P, Watson C, Hsu C, La Du BN (2000) Human serum paraoxonase (pon1) isozymes Q and $\mathrm{R}$ hydrolyze lactones and cyclic carbonate esters. Drug Metab Dispos 28: 1335-1342.

Bleich S, Degner D, Sperling W, Bonsch D, Thurauf N, Kornhuber J (2004) Homocysteine as a neurotoxin in chronic alcoholism. Prog Neuro-Psychoph 28: 453-464.

Boldyrev AA, Johnson P (2007) Homocysteine and its derivatives as possible modulators of neuronal and non-neuronal cell glutamate receptors in Alzheimer's disease. I Alsheimers Dis 11: 219-228.

Bønaa KH, Niølstad I, Ueland PM, Schirmer H, Tverdal A, Steigen T, Wang H, Nordrehaug JE, Arnesen E, Rasmussen K (2006) Homocysteine lowering and cardiovascular events after acute myocardial infarction. N Engl J Med 354: 1578-1588.

Bottiglieri T (2005) Homocysteine and folate metabolism in depression. Prog Neuro-Psychoph 29: 1103-1112.

Brosnan JT, Jacobs RL, Stead LM, Brosnan ME (2004) Methylation demand: a key determinant of homocysteine metabolism. Acta Biochim Pol 51: 405-413.

Cantoni GL (1985) The role of $S$-adenosylhomocysteine in the biological utilization of $S$-adenosyl-methionine. Prog Clin Biol Res 198: $47-65$.

Carluccio MA, Ancora MA, Massaro M, Carluccio M, Scoditti E, Distante A, Storelli C, De Caterina R (2007) Homocysteine induces VCAM-1 gene expression through NF- $x \mathrm{~B}$ and $\mathrm{NAD}(\mathrm{P}) \mathrm{H}$ oxidase activation: protective role of Mediterranean diet polyphenolic antioxidants. Am I Physiol-Heart C 293: H2344-H2354.

Castro R, Rivera I, Blom HJ, Jakobs C, Tavares de Almeida I (2006) Homocysteine metabolism, hyperhomocysteinaemia and vascular disease: an overview. I Inherit Metab Dis 29: 3-20.

Chan E-C, Chang P-Y, Wu T-L, Wu JT (2005) Enzymatic assay of homocysteine on microtiter plates or a TECAN analyzer using crude lysate containing recombinant methionine $\gamma$-lyase. Ann Clin Lab Sci 35: $155-160$

Chang P-Y, Lu S-C, Lee C-M, Chen Y-J, Dugan TA, Huang W-H, Chang S-F, Liao WSL, Chen C-H, Lee Y-T (2008) Homocysteine inhibits arterial endothelia cell growth through transcriptional downregulation of fibroblast growth factor-2 involving $G$ protein and DNA methylation. Circ Res 102: 933-941.

Chen H, Zhao Q, Wu Y, Li F, Yang H, Yi T, Huang C (2007) Selective phosphorescence chemosensor for homocysteine based on an iridium (III) complex. Inorg Chem 46: 11075-11081.

Chigurupati S, Wei Z, Belal C, Vandermey M, Kyriazis GA, Arumugam TV, Chan S (2009) The homocysteine-inducible endoplasmic reticulum stress protein counteracts calcium store depletion and induction of CCAAT enhancer-binding protein homologous protein in a neurotoxin model of Parkinson disease. J Biol Chem 284: 18323-18333.

Chwatko G, Jakubowski H (2005) The determination of homocysteinethiolactone in human plasma. Anal Biochem 337: 271-277.

Clarke R, Armitage J, Lewington S et al (2006) B-Vitamin Treatment Trialists' Collaboration: Homocysteine-lowering trials for prevention of cardiovascular events: a review of the design and power of the large randomized trials. Am Heart J 151: 282-287.

Clarke R, Collins R, Lewington S et al. (2002) Homocysteine Studies Collaboration: Homocysteine and risk of ischemic heart disease and stroke: a meta-analysis. JAMA 288: 2015-2022.

Dai CW, Zhang GS, Wu XP (2002) High-performance liquid chromatographic assay for plasma total homocysteine. Hunan Yi Ke Da Xue Xиe Bao 27: 556-558.

Dalal S, Parkin SM, Homer-Vanniasinkam S, Nicolaou A (2003) Effect of homocysteine on cytokine production by human endothelial cells and monocytes. Ann Clin Biochem 40: 534-541.

Daneshvar P, Yazdanpanah M, Cuthbert C, Cole DE (2003) Quantitative assay of plasma homocysteine thiolactone by gas chromatography/mass spectrometry. Rapid Commun Mass Sp 17: 358-362.

Dayal S, Arning E, Bottiglieri T, Boger RH, Sigmund CD, Faraci FM, Lentz SR (2004) Cerebral vascular dysfunction mediated by superoxide in hyperhomocysteinemic mice. Stroke 35: 1957-1962.

De Bree A, Verschuren WMM, Kromhout D, Kluijtmans LAJ, Blom HJ (2002) Homocysteine determinants and the evidence to what extent homocysteine determines the risk of coronary heart disease. Pharmacol Rev 54: 599-618.

Donnelly JG, Pronovost C (2000) Evaluation of the Abbott Imx ${ }^{\mathrm{TM}}$ fluorescence polarization immunoassay and the Bio-Rad enzyme immunoassay for homocysteine: comparison with high-performance liquid chromatography. Ann Clin Biochem 37: 194-198.

Edirimanne VER, Woo CWH, Siow YL, Pierce GN, Xie JY (2007) Homocysteine stimulates NADPH oxidase-mediated superoxide production leading to endothelial dysfunction in rats. Can J Physiol Pharm 85: 1236-1247.

Eikelboom JW, Hankey GJ, Anand SS, Lofthouse E, Staples N, Baker RI (2000) Association between high homocyst(e)ine and ischemic stroke due to large- and small-artery disease but not other etiologic subtypes of ischemic stroke. Stroke 31: 1069-1075.

Exner M, Hermann M, Hofbauer R, Hartmann B, Kapiotis S, Gmeiner B (2002) Homocysteine promotes the LDL oxidase activity of ceruloplasmin. FEBS Lett 531: 402-406.

Fermo I, Paroni R (2000) Total plasma homocysteine analysis by HPLC with SBD-F precolumn derivatization. In Amino Acid Analysis Protocols, Series: Methods in Molecular Biology Vol No 159. Cooper C, Packer N, Williams K, eds, pp 237-244. Humana Press Inc., Totova, NJ.

Finkelstein JD (1998) The metabolism of homocysteine: pathways and regulation. Eur J Pediatr 157: S40-Z44.

Frantzen F, Faaren AL, Alfheim I, Nordhei AK (1998) Enzyme conversion immunoassay for determining total homocysteine in plasma or serum. Clin Chem 44: 311-316.

Ganguly PK, Maddaford TG, Edel AL, O K, Smeda JS, Pierce GN (2008) Increased homocysteine-induced release of excitatory amino acids in the striatum of spontaneously hypertensine stroke-prone rats. Brain Res 1226: 192-198.

Glowacki R, Bald E (2009) Fully automated method for simultaneous determination of total cysteine, cysteinylglycine, glutathione and homocysteine in plasma by HPLC with UV absorbance detection. $J$ Chromatogr B Analyt Tecbnol Biomed Life Sci 877: 3400-3404.

Griffiths HR, Alfred S, Dale C, Nakano E, Kitas GD, Grant MG, Nuget D, Taiwo FA, Li L, Powers HJ (2006) Homocysteine from endothelial cells promotes LDL nitration and scavenger receptor uptake. Free Radical Biol Med 40: 488-500.

Guttormsen AB, Solheim E, Refsum H (2004) Variation in plasma cystathionine and its relation to changes in plasma concentrations of homocysteine and methionine in healthy subjects during a $24-\mathrm{h}$ observation period. Am I Clin Nutr 79: 76-79.

Hajjar KA, Mauri L, Jacovina AT, Zhong F, Mirza UA, Padovan JC, Chait B (1998) Tissue plasminogen activator binding to the annexin II tail domain. Direct moduation by homocysteine. J Biol Chem 273: 9987-9993.

Hansrani M, Stansby G (2007) Extended storage of whole blood with 3-deazaadenosine for homocysteine assay. Ann Clin Biochem 44: $388-390$.

Hanyu N, Shimizu T, Yamauchi K, Okumura N, Hidaka H (2009) Characterization of cysteine and homocysteine bound to human serum transthyretin. Clin Chim Acta 403: 70-75.

Ho PI, Ortiz D, Rogers E, Shea TB (2002) Multiple aspects of homocysteine neurotoxicity: glutamate excitotoxicity, kinase hyperactivation and DNA damage. I Neurosci Res 70: 694-702.

Hofmann MA, Lalla E, Gleason MR, Wolf BM, Tanji N, Ferran LJ, Kohl B, Rap V, Kisiel W, Stern DM, Schmidt AM (2001) Hyperhomocysteinemia enhances vascular inflammation and accelerates atherosclerosis in a murine model. I Clin Invest 107: 675-683.

Hong I, Fast W (2007) Inhibition of human dimethylarginine dimethylaminohydrolase- 1 by $S$-nitroso-L-homocysteine and hydrogen peroxide: analysis, quantification, and implications for hyperhomocysteinemia. J Biol Chem 282: 34684-34692.

Hortin GL, Seam N, Hoehn GT (2006) Bound homocysteine, cysteine, and cysteinylglycine distribution between albumin and globulins. Clin Chem 52: 2258-2264.

Houze P, Gamra S, Madelaine I, Bousquet B, Gourmel B (2006) Simultaneous determination of total plasma glutathione, homocysteine, cysteinylglycine, and methionine by high-performance liquid chromatography with electrochemical detection. J Clin Lab Anal 15: $144-153$.

Huang K, Yang H, Zhou Z, Chen H, Li F, Yi T, Huang C (2009) A highly selective phosphorescent chemodosimeter for cysteine and homocysteine based on platinum (II) complexs. Inorg Chim Acta 362: $2577-2580$

Hucks D, Thuraisingham RC, Raftery MJ, Yagoob MM (2004) Homocysteine induced impairement of nitric oxide-dependent vasorelaxation is reversible by the superoxide dismutase mimetic TEMPOL. Nephrol Dial Transpl 19: 1999-2005.

Hwang S-Y, Woo CWH, Au-Yeung KKW, Siow YL, Zhu TY, Karmin O (2008) Homocysteine stimulates monocyte chemoattractant protein-1 expression in the kidney via nuclear factor- $x \mathrm{~B}$ activation. $\mathrm{Am}$ J Physiol-Renal 294: F236-244.

Ichinose S, Nakamura M, Maeda M, Ikeda R, Wada M, Nakazato M, Ohba Y, Takamura N, Maeda T, Aoyagi K, Nakashima K (2009) 
A validated HPLC-fluorescence method with a semi-micro column for routine determination of homocysteine, cysteine and cysteamine, and the relation between the thiol derivatives in normal human plasma. Biomed Chromatogr 23: 935-939.

Jacobsen DW (2000) Hyperhomocysteinemia and oxidative stress: time for a reality check? Arterioscl Throm V as 20: 1182-1184.

Jacobsen DW, Savon SR, Stewart RW, Robinson K, Kottke-Marchant K, Di Corleto PE (1995) Limited capacity for homocysteine catabolism in vascular cells and tissues: a pathophysiologic mechanism for arterial damage in hyperhomocysteinemia? Circulation 91: 29-33.

Jakubowski H (1997) Metabolism of homocysteine thiolactone in human cell cultures. Possible mechanism for pathological consequences of elevated homocysteine levels. J Biol Chem 272: 1935-1942.

Jakubowski H (1999) Protein homocysteinylation: possible mechanism underlying pathological consequences of elevated homocysteine levels. FASEB J 13: 2277-2283.

Jakubowski H (2000) Calcium-dependent human serum homocysteine thiolactone hydrolase. A protective mechanism against protein $N$ homocysteinylation. J Biol Chem 275: 3957-3962.

Jakubowski H (2002a) Homocysteine is a protein amino acid in humans. Implications for homocysteine-linked disease. J Biol Chem 277: 30425-30428.

Jakubowski H (2002b) The determination of homocysteine-thiolactone in biological samples. Anal Biochem 308: 112-119.

Jakubowski H (2006) Pathophysiological consequences of homocysteine excess. J Nutr 136: 1741S-1749S.

Jakubowski H (2008a) The pathophysiological hypothesis of homocysteine thiolactone-mediated vascular disease. J Physiol Pharmacol 59: $155-167$.

Jakubowski H (2008b) New method for the determination of protein N-linked homocysteine. Anal Biochem 380: 257-261.

Jakubowski H, Boers GHJ, Strauss KA (2008) Mutations in cystathionine beta-synthase or methylenetetrahydrofolate reductase gene increase $N$-homocysteinylated protein levels in humans. FASEB J 22: 4071-4076.

Jakubowski H, Perla-Kajan J, Finnell RH, Cabrera RM, Wang H, Gupta S, Kruger WD, Kraus JP, Shih DM (2009) Genetic or nutritional disorders in homocysteine or folate metabolism increase protein N-homocysteinylation in mice. FASEB J 23: 1721-1727.

Jamaluddin MS, Chen I, Yang F, Jiang X, Jan M, Liu X, Schafer AI, Durante W, Yang X, Wang H (2007) Homocysteine inhibits endothelial cell growth via DNA hypomethylation of the cyclin A gene. Blood 110: 3648-3455.

Lentz SR, Haynes WG (2004) Homocysteine: It is a clinically important cardiovascular risk factor? Clev Clin J Med 71: 729-734.

Kamath AF, Chauhan AK, Kisucka J, Dole VS, Loscalzo J, Handy DE, Wagner DD (2006) Elevated levels of homocysteine compromise blood-brain barrier integrity in mice. Blood 107: 591-593.

Kataoka H, Takagi K, Makita M (1995) Determination of total plasma homocysteine and related aminothiols by gas chromatography with flame photometric detection. J Chromatogr B Biomed Appl 664: $421-425$.

Koubaa N, Nakbi A, Hammami S, Attia N, Mehri S, Ben Hamda K, Ben Farhat M, Miled A, Hammami M (2009) Association of homocysteine thiolactonase activity and PON1 polymorphism with the severity of acute coronary syndrome. Clin Biochem 42: 771-776.

Kruman II, Culmsee C, Chan SL, Kruman Y, Guo Z, Penix L, Mattson MP (2000) Homocysteine elicits a DNA damage response in neurons that promotes apoptosis and hypersensitivity to excitotoxicity. J Neurosci 20: 6920-6926.

Kuhn J, Gotting C, Kleesiek K (2006) Rapid micro-scale assay for homocysteine by liquid chromatography-tandem mass spectrometry. Clin Biochem 39: 164-166.

Lee M, Hong K-S, Chang S-C, Saver JL (2010) Efficacy of homocysteine-lowering therapy with folic acid in stroke prevention. Stroke 41: 1205-1212.

Li Z, Sun L, Zhang H, Liao Y, Wang D, Zhao B, Zhu Z, Zhao J, Ma A, Han Y, Wang Y, Shi Y, Ye J, Hui R (2003) Elevated plasma homocysteine was associated with hemorrhagic and ischemic stroke, but methylenetetrahydrofolate reductase gene C677T polymorphism was a risk factor for thrombotic stroke: a multicenter case-control study in china. Stroke 34: 2085-2090.

Lindgren A, Brattstrom L, Norrving B, Hultberg B, Andersson A, Johansson BB (1995) Plasma homocysteine in the acute and convalescent phase after stroke. Stroke 26: 795-800.

Liu G, Nellaiappan K, Kagan H (1997) Irreversible inhibition of lysyl oxidase by homocysteine thiolactone and its selenium and oxygen analogues. Implications for homocystinuria. J Biol Chem 272: 3237032377.

Lubos E, Loscalzo J, Handy DE (2007) Homocysteine and glutathione peroxidase-1. Antioxid Redox Sign 9: 1923-1940.

Majors AK, Sengupta S, Willard B, Kinter MT, Pyeritz RE, Jacobsen DW (2002) Homocysteine binds to human plasma fibronectin and inhibits its interaction with fibrin. Arterioscl Throm $V$ as 22: 1354 1359.
Martens GA, De Nayer J, De Smet D, Couck P, Gorus F, Gerlo E (2008) Homocysteine measurement by Vitros Microtip homocysteine assay. Clin Chem Lab Med 46: 283-286.

Martin SC, Hilton AC, Bartlett WA, Jones AF (1999) Plasma total homocysteine measurement by ion-paired reversed-phase HPLC with electrochemical detection. Biomed Chromatogr 13: 81-82.

Mattson MP, Shea TB (2003) Folate and homocysteine metabolism in neural plasticity and neurodegenerative disorders. Trends Neurosci 26: 137-146.

Moshal KS, Sen U, Tyagi N, Henderson B, Steed M, Ovechkin AV, Tyagi SC (2006) Regulation of homocysteine-induced MMP-9 by ERK1/2 pathway. Am J Physiol-Cell Ph 290: C883-891.

Mukai Y, Togawa T, Suzuki T, Ohata K, Tanabe S (2002) Determination of homocysteine thiolactone and homocysteine in cell cultures using high-performance liquid chromatography with fluorescence detection. J Chromatogr B Analyt Technol Biomed Life Sci 767: 263-268.

Nygard O, Nordrehaug JE, Refsum H, Ueland PM, Farstad M, Vollset SE (1997) Plasma homocysteine levels and mortality in patients with coronary artery disease. N Engl J Med 337: 230-237.

Outinen PA, Sood SK, Pfeifer SI, Pamidi S, Podor TJ, Li J, Weitz JI, Austin R (1999) Homocysteine-induced endoplasmic reticulum stress and growth arrest leads to specific changes in gene expression in human vascular endothelial cells. Blood 94: 959-967.

Patel KB, Stratford MR, Wardman P, Everett SA (2002) Oxidation of tetrahydrobiopterin by biological radicals and scavenging of the trihydrobiopterin radical by ascorbate. Free Radical Biol Med 32: 203211.

Perini F, Galloni E, Bolgan I, Bader G, Ruffini R, Arzenton E, Alba S, Azzini C, Bartolomei L, Billo G, Bortolon F, Dudine P, Garofalo PG, L'Erario R, Morra M, Parisen P, Stenta G, Toso V (2005) Elevated plasma homocysteine in acute stroke was not associated with severity and outcome: stronger association with small artery disease. Neurol Sci 26: 310-318.

Perla-Kajan J, Jakubowski H (2010) Paraoxonase 1 protects against protein $N$-homocysteinylation in humans. FASEB J 24: 931-936.

Perna AF, Satta E, Acanfora F, Lombardi C, Ingrosso D, De Santo NG (2006) Increased plasma protein homocysteinylation in hemodialysis patients. Kidney Int 69: 869-876.

Perry IJ, Refsum H, Morris RW, Ebrahim SB, Ueland PM, Shaper AG (1995) Prospective study of serum total homocysteine concentration and risk of stroke in middle-aged British men. Lancet 346: 13951398.

Pezzini A, Del Zotto E, Padovani A (2007) Homocysteine and cerebral ischemia: pathogenic and therapeutical implications. Curr Med Chem 14: 249-263.

Poddar R, Sivasubramanian N, DiBello PM, Robinson K, Jacobsen DW (2001) Homocysteine induces expression and secretion of monocyte chemoattractant protein-1 and interleukin- 8 in human aortic endothelial cells: implications for vascular disease. Circulation 103: 2717-2723.

Poddar R, Paul S (2009) Homocysteine-NMDA receptor-mediated activation of extracellular signal-regulated kinase leads to neuronal cell death. I Neurochem 110: 1095-1106.

Purohit V, Abdelmalek MF, Barve S, Benevenga NJ, Halsted CH, Kaplowitz N, Kharbanda KK, Liu Q-Y, Lu SC, McClain CJ, Swanson C, Zakhari S (2007) Role of S-adenosylmethionine, folate, and betaine in the treatment of alcoholic liver disease: summary of a symposium. Am J Clin Nutr 86: 14-24.

Raposo B, Rodriguez C, Martinez-Gonzalez J, Badimon L (2004) High levels of homocysteine inhibit lysyl oxidase (LOX) and downregulate LOX expression in vascular endothelial cells. Atherosclerosis 177: $1-8$.

Rasic-Markovic A, Stanojlovic O, Hrncic D, Krstic D, Colovic M, Susic V, Radosavljevic T, Djuric D (2009) The activity of erythrocyte and brain $\mathrm{Na}^{+} / \mathrm{K}^{+}$and $\mathrm{Mg}^{2+}$-ATPases in rats subjected to acute homocysteine and homocysteine thiolactone administration. Mol Cell Biochem 327: 39-45.

Rasmussen K, Moller J (2000) Total homocysteine determination in clinical practice. Ann Clin Biochem 37: 627-648.

Refsum H, Smith AD, Ueland PM, Nexo E, Clarke R, McPartlin J, Johnston C, Engbaek F, Schneede J, McPartlin C, Scott JM (2004) Facts and recommendations about total homocysteine determinations: an expert opinion. Clin Chem 50: 3-32.

Roberts RF, Roberts WL (2004) Performance characteristics of a recombinant enzymatic cycling assay for quantification of total homocysteine in serum or plasma. Clin Chim Acta 344: 95-99.

Salazar J-F, Herbeth B, Siest G, Leroy P (1999) Stability of blood homocysteine and other thiols: EDTA or acidic citrate? Clin Chem 45: 2016-2019.

Saposnik G, Ray JG, Sheridan P, McQueen M, Lonn E (2009) Homocysteine-lowering therapy and stroke risk, severity, and disability. Additional findings from the HOPE 2 Trial. Stroke 40: 1365-1372.

Sawuła W, Banecka-Majkutewicz Z, Kadziński L, Jakóbkiewicz-Banecka J, Węgrzyn G, Nyka W, Banecki B (2008) Improved HPLC method for total plasma homocysteine detection and quantification. Acta Biochim Pol 55: 119-125. 
Selley ML (2004) Homocysteine increases the production of asymmetric dimethylarginine in cultured neurons. J Neurosci Res 77: 90-93.

Spence JD, Bang H, Chambless LE, Stampfer MJ (2005) Vitamin intervention for stroke prevention trial: an efficacy analysis. Stroke 36: 2404-2409.

Spiroski I, Kedev S, Antov S, Arsov T, Krstevska M, Dzhekova-Stojkova S, Bosilkova G, Kostovska S, Trajkov D, Petlichkovski A, Strezova A, Efinska-Mladenovska O, Spiroski M (2008) Methylenetetrahydrofolate reductase (MTHFR-677 and MTHFR-1298) genotypes and haplotypes and plasma homocysteine levels in patients with occlusive artery disease and deep venous thrombosis. Acta Biochim Pol 55: $587-594$.

Stipanuk MH (2004) Sulfur amino acid metabolism: pathways for production and removal of homocysteine and cysteine. Annu Rev Nutr 24: 539-577.

Sunden SL, Renduchintala MS, Park EI, Miklasz SD, Garrow TA (1997) Betain-homocysteine methyltransferase expression in porcine and human tissues and chromosomal localization of the human gene. Arch Biochem Biophys 345: 171-174.

Syardal A, Refsum H, Ueland PM (1986) Determination of in vivo protein binding of homocysteine and its relation to free homocysteine in the liver and other tissues of the rat. J Biol Chem 261: 3156-3163.

Tan Y, Hoffman RM (2008) A highly sensitive single-enzyme homocysteine assay. Nat Protoc 3: 1388-1394.

Thampi P, Stewart BW, Joseph L, Melnyk SB, Hennings LJ, Nagarajan $\mathrm{S}$ (2008) Dietary homocysteine promotes atherosclerosis in apoEdeficient mice by inducing scavenger receptors expression. Atherosclerosis 197: 620-629.

Toole JF, Malinow MR, Chambless LE, Spence JD, Pettigrew LC, Howard VJ, Sides EG, Wang C-H, Stampfer M (2004) Lowering homocysteine in patients with ischemic stroke to prevent recurrent stroke, myocardial infarction, and death: the vitamin intervention for stroke prevention (VISP) randomized controlled trial. JAMA 291: $565-575$.

Topal G, Brunet A, Millanvoye E, Boucher J-L, Rendu F, Devynck M-A, David-Dufilho M (2004) Homocysteine induces oxidative stress by uncoupling of $\mathrm{NO}^{\bullet}$ synthase activity through reduction of tetrahydrobiopterin. Free Radical Biol Med 36: 1532-1541.

Tyagi N, Gillespie W, Vacek JC, Sen U, Tyagi SC, Lominadze D (2009) Activation of GABA-A receptor ameliorates homocysteine-induced MMP-9 activation by ERK pathway. J Cell Physiol 220: 257-266.

Tyagi SC, Lominadze D, Roberts AM (2005) Homocysteine in microvascular endothelial cell barrier permeability. Cell Biochem Biophys 43: 37-44.

Tyagi N, Moshal KS, Tyagi SC, Lominadze D (2007) Gamma-aminobutiric acid A receptor mitigates homocysteine-induced endothelial cell permeability. Endothelium 14: 315-323.

Ubbink JB (2000). Assay methods for the measurement of total homocyst(e)ine in plasma. Semin Thromb Hemost 26: 233-241.

Uji Y, Motomiva Y, Hanyu N, Ukaji F, Okabe H (2002) Proteinbound homocystamide measured in human plasma by HPLC. Clin Chem 48: 941-944.

Undas A, Perla J, Lacinski M, Trzeciak W, Kazmierski R, Jakubowski H (2004) Autoantibodies against $N$-homocysteinylated proteins in humans: implications for atherosclerosis. Stroke 35: 1299-1304.
Undas A, Kolarz M, Kopec G, Glowacki R, Placzkiewicz-Jankowska E, Tracz W (2007) Autoantibodies against N-homocysteinylated proteins in patients on long-term haemodialysis. Nephrol Dial Transpl 22: 1685-1689.

Ungvari Z, Sarkadi-Nagy E, Bagi Z, Szollar L, Koller A (2000) Simultaneously increased $\mathrm{TxA}_{2}$ activity in isolated arterioles and platelets of rats with hyperhomocysteinemia. Arterioscler Throm Vas 20: 1203-1208.

Wang H, Jiang XH, Yang F, Chapman GB, Durante W, Sibinga NES, Schafer AI (2002) Cyclin A transcriptional suppression is the major mechanism mediating homocysteine-induced endothelial cell growth inhibition. Blood 99: 939-945.

Wang X, Qin X, Demirtas H, Li J, Mao G, Huo Y, Sun N, Liu L, Xu $\mathrm{X}$ (2007) Efficacy of folic acid supplementation in stroke prevention: a meta-analysis. Lancet 369: 1876-1882.

Weiss N, Heydrick SJ, Postea O, Keller C, Keaney JF, Loscalzo J (2003) Influence of hyperhomocysteinemia on the cellular redox state - impact on homocysteine-induced endothelial dysfunction. Clin Chem Lab Med 41: 1455-1461.

Windelberg A, Arseth O, Kvalheim G, Ueland PM (2005) Automated assay for the determination of methylmalonic acid, total homocysteine, and related amino acids in human serum or plasma by means of methylchloroformate derivatization and gas chromatography-mass spectrometry. Clin Chem 51: 2103-2109.

Yamamoto M, Hara H, Adachi T (2000) Effects of homocysteine on the binding of extracellular-superoxide dismutase to the endothelial cell surface. FEBS Lett 486: 159-162.

Zappacosta B, Mordente A, Persichilli S, Minucci A, Carlino P, Martorana GE, Giardina B, De Sole P (2001) Is homocysteine a prooxidant? Free Radical Res 35: 499-505.

Zeng X, Dai J, Remick DG, Wang X (2003) Homocysteine mediated expression and secretion of monocyte chemoattractant protein-1 and interleukin-8 in human monocytes. Circ Res 93: 311-320.

Zhang C, Cai Y, Adachi MT, Oshiro S, Aso T, Kaufman RJ, Kitajima S (2001) Homocysteine induces programmed cell death in human vascular endothelial cells through activation of the unfolded protein response. J Biol Chem 276: 35867-35874.

Zhang D, Jiang X, Fang P, Yan Y, Song J, Gupta S, Schafer AI, Durante W, Kruger WD, Yang X, Wang H (2009) Hyperhomocysteinemia promotes inflammatory monocyte generation and accelerates atherosclerosis in transgenic cystathione $\beta$-synthase-deficient mice. Circulation 120: 1893-1902.

Zhang M, Pfeiffer CM (2004) Comparing the ESA HPLC total homocysteine assay with electrochemical detection to the CDC inhouse HPLC assay with fluorescence detection. Clin Chim Acta 340: 195-200.

Zou M, Jendral M, Ullrich V (1999) Prostaglandin endoperoxide-dependent vasospasm in bovine coronary arteries after nitration of prostacyclin synthase. Br J Pharmacol 126: 1283-1292.

Zou CG, Zhao YS, Gao SY, Li SD, Cao XZ, Zhang M, Zhang KQ (2010) Homocysteine promotes proliferation and activation of microglia. Neurobiol Aging 31: 2069-2079.

Zou CG, Banerjee R: Homocysteine and redox signaling (2005) Antioxid Redox Sign 7: 547-559. 